\title{
CICLO DE VIDA DA CRIANÇA JAVAÉ
}

\section{Ademir Kurisiri Javaé \\ Orientador de estudo}

\section{RESUMO}

A relação da vida começa entre homem e mulher durante seu primeiro casamento. Dentre alguns meses da vida cotidiana, quando a mulher atrasa sua menstruação, a partir daí começa a primeira geração da vida. No período de gestação a mulher começa comer comida preferida, uma coisa que a criança pede ao mundo. Após nove meses, a criança nasce da barriga da mãe. Antigamente somente as mulheres acompanhavam o parto, quem cuida nesse momento de parto é a parteira. Às vezes aparece o pajé (hyri) quando acontece ultrapassagem do tempo de nascimento da criança. Ao nascer a criança e todos os parentes dão o primeiro banho na face da terra, independente do sexo, logo em seguida recebe uma oferenda, conhecida como mel, todos os parentes que acompanharam durante esse evento comem o mel de europa, conhecido como boròtyrè.

PALAVRAS-CHAVE: Pajé. Mãe. Gestação. Criança. Nascimento.

\section{RYBĒNA KYJAKERE}

Iny bèdèdỹkỹnana hãwyky hãbu wana ribi raòrarunymyhỹre. Hãwyky tiusebo ahãdu riwidi tahè itèhè nakòròmyhỹde, iu tahè iny doimyhỹde, dèlèmyhỹde, iu hèka hãwyky aõmy naurarimyhỹde, iriòrè hèka tuu rexitòènymyhỹre tumyna tahè riroxirèrimyhỹre. Dèbò inaubiòwa ahãdu riwydi tahè uladu ruamyhỹre. Hỹkỹnau hèka hãwykyle uladu riijaranymyhỹre, uladu ijaradỹkỹdule. Aõwana hàri tamy rèhèmynymyhỹre uladu rarokorèhèny wana. Uladu ruamyhỹreu tahè isỹ risèbènymyhỹre, aõtxile uladu, weryry aõbo ỹda hirari aõbo, irahudi tahè isỹ mahãdu bidi-my dikòènymyhỹde, òròba ritòmyhỹre, tasỹ iu tamy isỹ mahãdu rabòròtyrèmyhỹre.

RYBÈ-WÈRYNA: Hàri. Inysè. Bòtò. Kuladu. Iny rukamyhỹre.

A relação da vida começa entre homem e mulher durante seu 
primeiro casamento. Dentre alguns meses da vida cotidiana, a mulher atrasa sua menstruação, a partir daí começa primeira geração da vida. No período de gestação a mulher começa comer comida preferida, uma coisa que a criança pede ao mundo. Após nove meses, a criança nasce da barriga da mãe. Antigamente só as mulheres acompanhavam os partos. Quem cuida nesse momento de parto é a parteira. Às vezes aparece o pajé (hyri) quando acontece ultrapassagem de tempo de nascimento da criança. Ao nascer a criança e todos os parentes dão o primeiro banho na fase da terra independente de sexo, logo em seguida recebe uma oferenda, conhecida como mel, todos os parentes que acompanharam durante a luz comem o mel de europa ou de açúcar, conhecido como boròtyrè que significa mais ou menos igualzinho. Essas pessoas como avó, avô, tia, tio, primos e outras pessoas são obrigadas a serem indagadas pela avó. Antigamente o pai ou parente mais próximo se organizava de guardar qualquer objeto para oferecer aos parentes, tais como: óleo de tucum ou de babaçu, esteira, canoa, miçanga, linha de algodão, arco e flecha, borduna ou cocar. Outros pedem comida, como tartaruga, peixe mais valioso. Por sua vez, a mulher fica de resguardo por um mês, sem tocar em comida como peixe e tartaruga, somente comida leve como bebida caluji e de uma caça. O pai da criança (tohouã tyby), também permanece em resguardo alguns dias, ele passa latxi (o riscador) que fazem esse saber são as pessoas que são preparadas como guerreiro, lutador. Atualmente as mulheres recebem os cuidados dos médicos, mesmo assim, quando chegam à aldeia de origem, recebem estes saberes para não esquecer a nossa tradição.

Obs.: A pesquisa continua... 